\title{
水利水电建筑工程降低施工成本的有效对策
}

\author{
方永福 \\ 浙江开化县方兴水利建设有限公司 \\ DOI:10.32629/hwr.v3i3.2004
}

[摘 要] 改革开放四十年以来, 我国各项事业都取得了巨大的发展。水利水电工程取得了重大的进步, 而作为水利水电工程重 要组成部分的水利水电建筑工程, 更是有着其独特的特点。本文从施工项目的特点出发, 分析成本控制中存在的不足, 最终提出 了若千解决措施。

[关键词] 施工成本; 解决措施; 施工; 水利水电

\section{1 水利水电建筑工程施工项目的特点}

随着社会的不断进步发展, 水利水电建筑工程也得到了 迅速的发展, 和传统的建筑工程施工项目相比, 水利水电工 程施工有着自身的优点, 包括, 投资高回报慢、工程施工需要 因地制宜、工程程序繁琐成本控制比较难等等。

1.1 投资高回报慢

作为我国基础建设最重要的组成之一, 水利水电建筑工 程存在着自己的特色。首先是施工地点偏僻, 施工环境差。水 利水电建筑工程项目绝大多数是在很偏远的地方, 交通不方 便, 施工环境也是较为恶劣的。其次是工程复杂投资高。水利 水电建筑工程需要消耗大量的金钱和各种资源。最后是回报 慢。水利水电建筑工程项目一般的施工工期很长, 得到回报 的时间也很长。

\section{2 工程复杂因地制宜}

水利水电建筑工程对于施工环境的要求很严格。一是工 程及其复杂。水利水电建筑工程项目涉及的范围很大, 涉及 到的部门也很多, 需要使用的技术也积极复杂。而自然环境 的特殊性和时常变化的天气, 更是加剧了施工难度。二是需 要因地制宜。由于工程的复杂性, 就需要在施工前对每个环 节进行仔细推敲, 每个环节都要责任到人, 每一个工序的施 工技术都要提前谋划好。在做好预案的基础上, 综合相关要 求和具体的施工环境, 进行合理的施工, 最终保证工程顺利 完成。

\section{3 工程繁琐价格多变}

由于水利水电建筑工程项目存在着工程复杂的特点, 直 接导致其预算难以制定和实施。一方面是非人为因素的影响 大。由于工程项目受到多种因素的影响, 包括自然环境、时 常变化天气及工程项目自身的复杂, 种种因素导致预算难以 制定。就算制定了之后, 由于非人为因素的影响, 预算还要随 时调整。另一方面是突发情况的出现。在工程施工中经常会 出现因为交通、水电等方面出现问题, 而导致工程难以进行。 由于这两大方面的原因, 就要求在制定和实施工程预算的时 候, 要注意考虑到合理弹性, 只有这样, 才能应对各种突发情 况, 保障工程顺利开展。

\section{2 水利水电建筑工程施工成本控制存在的问题}

成本控制是水利水电建筑工程施工的重要组成部分, 也 是影响工程企业竞争力的重要因素。虽然近年来水利水电建 筑工程施工项目成本控制得到了很大的改善, 但是, 就目前 的情况来看, 仍然存在着一些问题, 常见的问题有以下几个 方面:

2.1 施工成本控制没有完备依据

水利水电建筑工程中, 施工成本控制工作容易出问题, 最大的原因就是成本控制没有完备依据。一是成本控制没有 因地制宜。由于每一个工程都变化很大, 就导致如果按照其 他工程的成本控制要求照葫芦画慓直接拿过来用, 将会造成 严重不合适的情况。如果这样的成本控制直接使用, 将对工 程造成严重的负面影响。二是成本控制过于简单机械。对于 成本控制只是在大方向上制定目标, 却忽视了对每一个环节 的成本控制。这样就直接导致口号喊得棒喊得响, 却是没法 真正实施。三是成本控制权威性不够。很多施工单位, 尤其 是分包的中小施工企业, 根本都没有顶尖的施工管理人才, 现有的人员根本达不到具体工程的要求。更值得注意的是, 企业自身就没有认识到成本控制的重要性, 忽视了对于现 有人员的培训, 对于最新的规定和政策也没有及时掌握。在 这样的情况下, 成本控制只能是无源之水无本之木, 只能是 喊口号。

\section{2 缺乏工程项目业绩奖励机制}

水利水电建筑工程项目想要能顺利完成, 人员管理无疑 是最重要的因素。但是现在存在的问题就是没有合理的奖励 机制, 导致人员控制出现漏洞。目前来看能够承担水利水电 建筑工程的以大中国企居多。而国企中往往存在按资排辈的 习惯, 权力也都是相对居中。虽然后奖励机制, 但是和资本运 营的民营企业相比, 还是要差不少。这样就会造成干的多错 的多罚的多, 不利于员工发挥主观能动性, 制约着工程项目 完成。

\section{3 在成本的管理上存在误区}

在现在的企业里, 成本控制是需要所有部门参与的。但 是目前很多企业和人员, 都有着思维惯性, 认为成本管理控 制都是财务的事, 和自己没关系。而财务人员也缺乏沟通意 识, 抱着多一事不如少一事的思想, 该提醒的不提醒, 一直等 
到出了问题才相互推诿。却没有意识到, 在当今环境下, 成本 控制是企业生存的生命线, 与每一位职工息息相关, 绝对不 是哪一个人的事情。

\section{3 水利水电建筑工程降低施工成本的有效办法}

3.1 做好工程施工前的准备工作

做好准备工作, 是水利水电建筑工程能够正常运行的最 重要的保证。一方面要制定要预案。预案要周密而全面, 对 每一个环节都要考虑周全, 明确每一个人的任务和责任, 所 有工作都要层层压实。另一方面是要对人员、设施等提前配 备好。要提前对人财物都算好, 保证每个阶段的工作都能顺 利完成。

\section{2 制定健全可行的原始记录制度}

原始记录是反映施工和管理活动的原始资料, 是进行成 本预测、成本控制、消耗分析和施工索赔的重要依据, 是施工 成本控制最基础的工作。所以进行原始记录必须以切实可行 的管理制度和技术保障制度作为支撑, 相关的记录人员对技 术、施工、合同、设备和劳资等相关部门的工作要进行协调, 保证原始记录的真实有效, 能保证其符合施工的具体要求, 要 保证原始记录能为工程的具体审核、等级等提供便利, 保证规 范的管理制度的形成, 保证成本控制的相关资料的完善。

\section{3 建立有效的激励约束机制}

通过建立约束激励的相关机制, 对管理人员能够有效的 进行调动, 这是具体的进行成本控制的方法之一。进行成本 管理的过程中, 通过激励约束机制, 能够确立具体的分配改 革的制度, 这样对经营者的工作积极性能够有效的调动, 将 经营的业绩与管理者的收入进行关联, 能够起到一定的约束 作用, 保证经营的风险和利益相互结合, 同时要保证分配制 度的科学合理有效, 保证各项考核的持续有效技能型, 这样 才能有效的进行成本的控制。

\section{4 推广项目成本核算}

可操作性强的、合理的内部成本核算定额的制定, 是从 人、财、物的配置入手, 根据工程施工实际条件, 结合行业统 一定额为依据而成的。其主要是对工程的机械费、人工费、 管理费和材料费进行核算与分析, 其中对机械费的管理以充 分发挥设备效率为目的, 实行以设备运行费为基准; 人工费 管理实行产值工资、效益工资和基本工资的结合; 材料费管 理主要是严格控制采购库存量, 实行以内部核算定额消耗为 基准, 同时, 在各作业队设立安全质量专项奖和目标激励奖,
建立利益激励机制; 把主辅材料费用支出和消耗水平与完成 工程量挂钩, 严格考核奖罚, 从而增强作业队的成本核算意 识, 做到节省材料、减少超挖、尽可能多的完成工作量, 从而 提高工效和设备的利用。

3.5 加强合同管理

施工企业管理的过程中, 合同管理是其中一项重要内容, 它能够帮助施工企业更好的降低工程成本, 提高施工的经济 效益。关于合同的管理问题, 要从合同的谈判签订开始, 保证 合同各项内容的如期完成, 按照合同规定的各项内容进行成 本的具体控制, 保证合同各项内容的具体实施。

3.6 材料费的控制

工程施工的过程中, 材料费占了其中很大的一部分, 因 此对材料的使用情况要进行严格的控制, 对相关的材料费的 型号规格、对材料的使用计划要进行相应的控制。要做好材 料进场验收工作, 保证施工材料的质量, 保证材料的数量, 在 施工的过程中严禁浪费, 施工完毕要做好材料的管理和收尾 工作。

3.7 机械费的控制

一般来说机械费用的编制使用计划出现在细化施工组 织设计后, 通过调整后的单价进行分析所得。进行施工的过 程中, 要做好机械的使用保养工作, 及时的进行机械的维修, 合理的安排作业, 保证机械的使用科学和设备的高效运转, 做好相关的管理工作。

综上所述, 水利水电建筑工程项目成本控制, 是一项综 合复杂的系统工程, 在降低其成本工作中必须要认真做好项 口成本预测, 通过计划、组织、控制和协调等环节实现预定 的成本目标, 科学有效的降低成本费用, 从而实现企业的投 资效益和社会效益。

\section{[参考文献]}

[1]吕泽锡.浅析水利水电建筑工程降低施工成本的有 效方法[J].科技资讯,2013,(06):160。

[2]赵勇.浅析水利水电工程的施工成本控制 [J].现代经 济信息,2010,(5):72.

[3]吴强国.水利水电工程施工成本控制 [J]. 黑龙江水利 科技,2012,(11):246-247.

[4]毛新宪,毛宁.水利水电工程施工成本控制探讨 [J].科 技信息,2012,(3):364+390. 